\title{
HUBUNGAN ANTARA CITRA MEREK DENGAN MINAT BELI HAND BODY LOTION PADA SISWA-SISWI KELAS XI DI SMA 2 CIPOCOK JAYA KOTA SERANG
}

\author{
${ }^{1)}$ Meilla Dwi Nurmala, ${ }^{2)}$ Aria Mulyapradana, ${ }^{3)}$ Meitami Sofiyanti \\ ${ }^{1)}$ Dosen Program Studi Bimbingan dan Konseling, Universitas Sultan Ageng Titrayasa \\ Email: meilla.dwi.nurmala@untirta.ac.id \\ ${ }^{2)}$ Dosen Program Studi Administrasi Perkantoran, Politeknik Pusmanu \\ Email: ariamulyapradana@gmail.com \\ ${ }^{3)}$ Mahasiswa Program Studi Bimbingan dan Konseling, Universitas Sultan Ageng Tirtayasa \\ Email: meitamisofiyanti@gmail.com
}

\begin{abstract}
Teenagers are potential consumers for skin care products such as hand body lotion because in their teens they want to try new things. Seeing this phenomenon, the manufacturers of skin care products competing to captivate the hearts of consumers by growing a positive brand image to adolescents, causing interest in buying hand body lotion. Based on this, a hypothesis emerged that students tend to be interested in buying hand body lotion from brands with positive images. Therefore, the purpose of this study was to obtain a picture of the relationship between brand image and buying interest at students of SMAN 2 Cipocok Jaya, Serang City. The method used is quantitative by using SPSS version 12.0 and the method of data collection by observation, interviews and distributing questionnaires to students of Cipocok Jaya Serang City with 123 people. Data collection techniques using a questionnaire with a Likert scale, each of which has been tested using validity and reliability. The data analysis used a bivariate correlation analysis and hypothesis testing using the $t$ test so that the results show that there is a positive relationship between brand image and buying interest in Class XI students of SMAN 2 Cipocok Jaya, Serang City, this is evidenced by the results of the correlation coefficient of brand image with buying interest ( $r$ ) equal to 0.332 and $p=0,000$ with $p<0.05$.
\end{abstract}

Keywords: Brand Image, Buying Interest, Teenagers, Hand Body Lotion.

\begin{abstract}
ABSTRAK
Remaja merupakan konsumen pontensial untuk produk perawatan kulit seperti hand body lotion, karena pada masa remaja ini mereka ingin mencoba hal-hal yang baru. Melihat fenomena tersebut, para produsen produk perawatan kulit berlomba-lomba untuk memikat hati konsumennya dengan cara menumbuhkan citra merek positif kepada remaja sehingga menimbulkan minat untuk beli hand body lotion. Berdasarkan hal ini, timbulah sebuah hipotesis bahwa siswa-siswa cenderung berminat untuk membeli hand body lotion yang berasal dari merek dengan citra yang positif. Oleh sebab itu tujuan dari penelitian ini untuk memperoleh gambaran serta menguji hipotesis hubungan antara citra merek dengan minat beli siswa-siswi SMAN 2 Cipocok Jaya Kota Serang. Metode yang digunakan adalah metode kuantitatif dengan menggunakan SPSS versi 12.0 sedangkan metode pengumpulan data adalah dengan cara observasi, wawancara dan menyebarkan kuesioner kepada siswa-siswi SMAN 2 Cipocok Jaya Kota Serang dengan jumlah 123 orang. Teknik pengumpulan data menggunakan kuesioner dengan skala likert, yang masing-masing telah diuji menggunakan validitas dan reliabilitas. Analisa data yang digunakankan yakni analisis kolerasi bivariate dan pengujian hipotesis menggunakan uji t sehingga didapatkan hasil bahwa terdapatnya hubungan positif antara citra merek dengan minat beli pada siswa-siswi Kelas XI SMAN 2 Cipocok Jaya Kota Serang, dan hal ini dibuktikan dengan didapatkannya hasil koefisien antara korelasi citra merek dengan minat beli (r) sebesar 0,332 dan $p=0,000$ dengan $p<0,05$.
\end{abstract}

Kata kunci : Citra Merek, Minat Beli, Remaja, Hand Body Lotion. 


\section{PENDAHULUAN}

\subsection{Latar Belakang}

Indonesia merupakan negara yang beriklim tropis yang memiliki suhu hangat dan disinari oleh sinar matahari sepanjang tahun serta memiliki luas 40 persen dari total permukaan dunia dan memiliki 80 persen keanekaragaman hayati dunia. Sinar matahari yang terpancar sepanjang tahun ini memiliki manfaat yang banyak terutama bagi tubuh salah satunya adalah terpenuhinya kebutuhan vitamin D yang berguna dalam mempengaruhi proses pembentukan tulang. Saat ini, perubahan suhu udara yang ekstrim berdampak pada kondisi fisik manusia khususnya kulit manusia. Kulit merupakan bagian tubuh yang memiliki dampak paling besar terhadap perubahan iklim tersebut seperti penuaan diri, risiko kanker kulit, kulit terbakar dan kulit terasa kering. Untuk meminimalisir terpaparnya bahaya negatif dari sinar matahari dan perubahan suhu yang ekstrim banyak cara yang dilakukan salah satunya dengan menggunakan hand body lotion.

Perkembangan sosial pada masa remaja mengalami perubahan sehingga mereka mengalami kesulitan di masa ini sebab mereka berhubungan dengan penyesuaian sosial. Penyesuaian sosial ini dapat diartikan sebagai kemampuan untuk mereaksi secara tepat terhadap realita sosial, situasi, dan relasi. Remaja dituntut untuk memiliki kemampuan penyesuaian sosial dengan baik dalam lingkungan keluarga, sekolah dan masyarakat. Pada perkembangan ini pula mereka terdorong untuk menjalin hubungan sosial yang lebih akrab, baik dengan jalinan persahabatan maupun percintaan. Berkembang juga sikap conformity yakni kecenderungan untuk menyerah atau mengikuti opini, pendapat, nilai, kebiasaaan, kegemaran atau keinginan orang lain (Anekasari, 2017).

Melihat perkembangan di masa remaja ini tersebut tak jarang para produsen atau pelaku bisnis yang menjadikan remaja sebagai target potensial dari produk yang dipasarkan. Untuk menarik hati konsumennya maka produsen berlombalomba meningkatkan citra merek yang positif kepada calon konsumennya agar mereka membeli produk yang ditawarkannya. Berdasarkan fenomena tersebut maka peneliti tertarik untuk meneliti tentang "Hubungan antara Citra Merek dengan Minat Beli untuk Hand Body Lotion Pada Siswa-Siswi Kelas XI di SMAN 2 Cipocok Jaya Kota Serang”.

\section{TINJAUAN PUSTAKA}

\subsection{Landasan Teori}

Hand body lotion merupakan produk salah satu produk perawatan kulit yang memiliki banyak manfaat seperti menjaga kelembaban kulit, mencegah kulit bersisik dan kusam, melembutkan kulit, memberikan perlindungan kulit dan memiliki aroma yang membuat tenang. Penggunaan hand body lotion sangat bermanfaat bagi penggunannya oleh karena itu banyak konsumen berminat untuk membeli hand body lotion sehingga banyak produsen produk hand body lotion berlomba-lomba untuk menjual dan memberikan informasi terhadap keunggulan-keunggulan dari produk tersebut agar konsumen berminat untuk membeli produk tersebut.

Agar produk yang dipasarkan dapat menarik perhatian para konsumen ada beberapa cara yang dilakukan seperti kemasannya menarik, praktis, aromanya segar, produk dapat ditemukan di pasar tradisional maupun pasar modern dan harga yang ekonomis bagi konsumen bahkan ada beberapa produsen memberikan penawaran yang menarik seperti memberikan diskon setiap konsumen membeli produknya. Untuk menjangkau wilayah pemasaran dan konsumen tak jarang produsen melakukan kegiatan promosi dengan cara mengiklankan produknya. Iklan merupakan bagian dari konsep marketing mix (4P) yakni : product, place, price dan promotion. 
Iklan merupakan alat yang digunakan oleh perusahaan untuk mengarahkan konsumen ditujukkan pada pembeli sasaran dan masyarakat. Dalam membuat iklan hal yang harus diperhatikan seperti mengindentifikasi pasar dan motif membeli. Disamping itu, iklan yang disampaikan kepada konsumen dengan menggunakan kata-kata dan ilustrasi akan menjadi menarik perhatian konsumen karena daya tarik iklan sangat penting dalam meningkatkan komunikasi dengan permisa sehingga memungkinkan konsumen untuk memilih produk berdasarkan iklan tersebut (Parmin, 2013). Formula AIDA (Attention, Interest, Desire, Action) merupakan formula yang paling sering digunakan untuk membantu perencanaan suatu iklan secara menyeluruh, dan formula itu dapat diterapkan pada suatu iklan (Kotler \& Keller, 2009).

\subsection{Minat Beli}

Perhatian (attention) yang diberikan dari konsumen merupakan awal dari minat untuk membeli produk yang ditawarkan. Minat beli merupakan respon yang muncul terhadap objek atau keinginan untuk membeli ulang (Parmin, 2013). Menurut Kotler dan Keller mengemukakan bahwa minat beli konsumen adalah sebuah perilaku konsumen dimana konsumen mempunyai keinginan dalam membeli atau memilih suatu produk, berdasarkan pengalaman dalm memilih, menggunakan dan mengkonsumsi atau bahkan menginginkan suatu produk (Sari \& Widowati, 2014). Pengertian minat beli menurut (Kotler \& Keller, 2009) minat beli merupakan perilaku yang muncul sebagai respon terhadap objek yang menunjukkan keinginan konsumen untuk melakukan pembelian.

Ada lima aspek motivasional terkait dengan minat beli diantaranya adalah (Berkman, H.W. Gilson, 1981):
1. Motif fungsional yaitu membeli berdasarkan fungsi dan kegunaan produk.

2. Motif emosional atau estetika yaitu mementingkan penampilan dan kenyamanan dari suatu produk seperti yang bagus, nyaman dipakai.

3. Motif sosial yaitu mengutamakan status atau nilai-nilai yang dikandung suatu produk seperti pujian.

4. Motif ingin tahu yaitu merupakan motif yang mendorong untuk mencoba suatu produk, merek atau model baru.

Minat beli merupakan bagian dari proses pengambilan keputusan, adapun tahapan dalam keputusan pembelian (Kotler dan Amstrong, 2008) antara lain :

1. Pengenalan masalah, proses dimulai ketika pembeli mengenali masalah atau kebutuhan.

2. Pencarian informasi, konsumen mencari informasi lebih banyak terhadap kebutuhannya.

3. Evaluasi alternatif, konsumen dalam mengolah informasi merek yang bersaing dan membuat penilaian akhir, tidak hanya menggunakan proses evaluasi tunggal sementara.

4. Keputusan pembelian, konsumen biasanya akan kembali membeli merek yang paling disukai, tetapi ada dua faktor bisa muncul antara niat pembelian dan keputusan pembelian.

5. Perilaku purna pembelian, konsumen akan mengalami level kepuasan atau ketidakpuasan terhadap produk yang sudah dibelinya.

\subsection{Citra Merek}

Salah satu faktor yang mempengaruhi konsumen dalam membeli produk yakni merek dari produk tersebut dan memiliki peranan penting dalam pengambilan keputusan. Merek (Parmin, 2013) merupakan bagian yang penting dari perusahaan karena merek dapat membedakan produk satu dengan produk 
yang lainnya. Dengan membangun merek yang kuat perusahaan dapat bersaing dengan merek lainnya untuk menarik minat membeli para konsumennya. Merek menurut Amarica Marketing Association mendefinisikan a Brand is name, term, sign, symbol or design or a combination of them, intended to identify the goods or service of one seller or grop of seller and to differentiate them from these of competitors (Sari \& Widowati, 2014).

Faktor-faktor pembentukan merek adalah sebagai berikut (Schiffman \& Kanuk, 2008) :

1. Kualitas atau mutu, berkaitan dengan kualitas produk yang ditawarkan oleh produsen dengan merek tertentu.

2. Dapat dipercaya atau diandalkan, berkaitan dengan pendapat dan kesepakatan yang di bentuk oleh masyarakat tentang suatui produk yang dikonsumsi.

3. Kegunaan atau manfaat, yang terkait dengan fungsi dari suatu produk yang bisa dimanfaatkan oleh konsumen.

4. Pelayanan, yang berkaitan dangan tugas produsen dalam melayani konsumennya.

5. Resiko berkaitan dengan untung rugi yang dialami oleh konsumen.

6. Harga, dalam hal ini berkaitan dengan tinggi rendahnya atau banyak sedikitnya jumlah uang yang dikeluarkan konsumen untuk mempengaruhi suatu produk, juga dapat mempengaruhi citra jangka panjang.

7. Image, yang dimiliki merek itu sendiri, yaitu berupa pelanggan, kesempatan dan informasi yang berkaitan dengan suatu merek dari produk tertentu.

Citra merek merupakan salah satu tahap dalam hirarki komunikasi merek (hierarchy of branding), citra merek memegang peranan penting dalam pengembangan sebuah merek karena citra merek menyangkut reputasi dan kredibilitas merek yang kemudian menjadi pedoman bagi khalayak konsumen untuk mencoba atau menggunakan suatu produk barang atau jasa sehingga menimbulkan pengalaman tertentu dan menentukan konsumen tersebut akan loayal terhadap merek tersebut atau sekedar oportunis (mudah pindah ke lain merek) (Lusi et al., 2016).

Citra merek ialah sekumpulan asosiasi merek yang terbentuk dan melekat dibenak konsumen. Konsumen yang terbiasa menggunakan merek tertentu cenderung memiliki konsistensi terhadap citra merek (Roisah \& Riana, 2016). Citra terhadap merek berhubungan dengan sikap yang berupa keyakinan dan preferensi terhadap suatu merek. Konsumen yang memiliki citra yang positif terhadap suatu merek, akan lebih memungkinkan untuk melakukan pembelian. Citra merek yang berbeda dan unik merupakan hal yang paling penting, karena produk semakin kompleks dan pasar semakin penuh, sehingga konsumen akan semakin bergantung pada citra merek daripada atribut merek yang sebenarnya untuk mengambil keputusan pembelian (Parmin, 2013).

Menurut Kamus Besar Bahasa Indonesia (KBBI, 2016), citra (image) adalah pemahaman kesan yang timbul karena pemahaman akan suatu kenyataan. Menurut Keller (A. Shimp, 2014) menyatakan bahwa berdasarkan perspektif konsumen, sebuah merek yang memiliki ekuitas sebesar pengenalan konsumen atas merek tersebut dan menyimpannya dalam memori mereka beserta assosiasi merek yang mendukung, kuat, dan unik. Melalui media promosi periklanan dan penanaman ekuitas merek yang baik kepada konsumen maka akan menimbulkan minat beli konsumen dalam melakukan pembelian produk atau jasa. Suatu merek memiliki dimensi fisik dan psikologis, dimensi fisik berupa warna, desain, kemasan logo, bentuk dan segala karakteristik fisik dari 
produk. Sedangkan dimensi psikologis terdiri dari (Foxall et al., 1998):

1. Kepribadian merek, mendesripskikan kesan apa yang ditampikan kepada konsumen melalui penciptaan iklan dan pengemasan.

2. Konotasi merek, merupakan apa yang dipikirkan konsumen mengenai merek tersebut juga bentuk-bentuk bagian dari citra itu sendiri.

3. Keuntungan merek, merupakan penilaian evaluatif terhadap karakteristik penampilan merek yang dimiliki dengan merek lain.

4. Pemakai, merek yang berasosiasi kuat pada profil pengguna yang unik atau type of user dari merek tertentu.

5. Situasi, beberapa merek dapat didentifikasi dengan situasi penggunaan tertentu.

Salah satu bagian masyarakat yang menunjukkan gejala ke arah konsumenrisme adalah remaja. Perkembangan masa remaja merupakan masa transisi perkembangan antara masa kanak-kanak dan dewasa yang umumnya dimulai pada usia 12 tahun atau 13 tahun dan berakhir di usia 20 tahun. Pada masa remaja dikenal juga dengan masa pubertas yakni masa perubahan dari makhluk aksesual menjadi makhluk seksual, dimana terjadi kematangan alat-alat seksual dan tercapainya kemampuan reproduksi.

Disamping itu pada masa pubertas terjadi perubahan perkembangan baik secara biologi maupun psikologis. Dari semua perubahan di masa ini, perkembangan fisik menjadi pengaruh terbesar di masa ini karena adanya perubahan-perubahan seperti pertumbuhan tubuh, mulai berfungsinya alat-alat reproduksi yang ditandai haid pada wanita dan mimpi basah pada pria serta ditandai dengan pertumbuhan tanda-tanda sekunder sehingga menyebabkan kecanggungan bagi remaja dan mereka harus menyesuaikan diri dengan perubahan-perubahan tersebut (Anekasari, 2017).

Tabel 1. Dimensi Variabel Citra Merek dan Minat Beli

\begin{tabular}{|c|l|}
\hline Variabel & \multicolumn{1}{|c|}{ Dimensi } \\
\hline Indenpendent & Kepribadian merek, \\
Variabel $(\mathrm{X}):$ & Konotasi merek, \\
Citra Merek & Keuntungan merek, \\
& Pemakai, Situasi, \\
\hline Dependent & Fungsional, \\
Variabel $(\mathrm{Y}):$ & Emosional. Sosial. \\
Minat Beli & Rasa Ingin tahu \\
\hline
\end{tabular}

\section{METODE PENELITIAN}

\subsection{Populasi dan Sampel}

Populasi merupakan keseluruhan objek yang akan diteliti dengan karakteristik tertentu, jelas dan lengkap (Mulyapradana et al., 2020). Populasi dalam penelitian ini adalah siswa-siswi Kelas XI SMAN 2 Cipocok Jaya Kota Serang berjumlah 180 orang, berdasarkan tabel nomogram Harry King (Sugiyono, 2016), sampel dalam penelitian ini berjumlah 123 orang dari jumlah populasi yang ada.

\subsection{Lokasi dan waktu Penelitian}

Lokasi penelitian ini dilakukan di SMAN 2 Cipocok Jaya Kota Serang.

\subsection{Jenis Penelitian}

Penelitian ini melibat dua variabel yakni variabel indenpenden dan variabel dependent. Variabel indenpenden (Elshifa, 2018) merupakan variabel yang mempengaruhi atau menjadi sebab timbulnya atau berubahnya variabel dependen (variabel terikat) dalam penelitian ini variabel independennya adalah citra merek. Variabel dependen dalam penelitian ini adalah minat beli.

Dengan menggunakan kuisioner yang ditujukan pada responden yang berisi pernyataan-pernyataan mengenai citra merek dan minat beli. Pernyataanpernyataan ini diukur dengan menggunakan 
skala likert dan teknik analisa dalam penelitian ini yakni SPSS versi 12. Metode analisis data menggunakan uji validitas, uji reliabitias dan analisis kolerasi bivariate serta untuk mengetahui pengaruh masingmasing variabel menggunakan uji $\mathrm{t}$.

\subsection{Kerangka Pemikiran}

\begin{tabular}{c|c|c|} 
Citra \\
Merek $(\mathrm{X})$
\end{tabular}$\stackrel{\mathrm{H} 1}{\begin{array}{c}\text { Minat Beli } \\
(\mathrm{Y})\end{array}}$

Gambar 1. Kerangka Pemikiran

Keterangan :

$\begin{aligned} \longrightarrow & : \text { Hubungan } \\ \text { H1 } & \text { Ada Hubungan antara Citra } \\ & \text { Merek dengan Minat Beli }\end{aligned}$

Penelitian ini dilakukan untuk mengkaji terdapat hubungan antara citra merek dengan minat membeli pada siswasiswi SMAN 2 Cipocok Jaya Kota Serang. Dalam penelitian ini terdapat hubungan antara citra merek dengan minat beli hal ini sejalan dengan penelitian terdahulu yang dilakukan oleh Endro Arifin dan Achmad Fachrodji dimana hasil penelitian yang dilakukan menujukkan bahwa variabel citra merek secara parsial berpengaruh signifikan terhadap minat beli. Sedangkan variabel persepsi kualitas dan variabel promosi secara parsial tidak berpengaruh signifikan terhadap minat beli. Secara simultan, ketiga varibel bebas yaitu persepsi kualitas, citra merek dan promosi berpengaruh signifikan terhadap minat beli (Endro \& Achmad, 2015).

Hal senada dari hasil penelitian yang dilakukan oleh Niken Permata Sari dan Retno Widowati $\mathrm{P}$, dalam penelitian ini menunjukkan bahwa kesadaran merek berpengaruh signifikan terhadap niat beli. Kesadaran merek dan kualitas persepsian mempunyai pengaruh yang signifikan dan positif terhadap kepercayaan merek. Hasil lain dalam penelitianini menunjukkan bahwa tidak ada pengaruh positif dari kualitas persepsian dan kepercayaan merek terhadap niat beli produk hijau (Sari \& Widowati, 2014).

Hasil penelitian yang dilakukan oleh Ida Ayu Putu Dian Savitri dan I Made Wardana dalam (Savitri \& Wardana, 2018) ditemukan bahwa citra merek, kualitas produk dan persepsi harga berpengaruh positif dan signifikan terhadap kepuasan pelanggan. Citra merek merupakan variabel yang paling dominan berpengaruh terhadap kepuasan pelanggan. Kepuasan pelanggan juga memiliki pengaruh positif dan signifikan terhadap niat beli ulang. Sehingga dapat disimpulkan bahwa menciptakan niat beli ulang pada konsumen dapat dilakukan dengan meningkatkan kepuasan pelanggan (Savitri \& Wardana, 2018).

\subsection{Teknik Analisis Data}

Teknik pengumpulan data yang digunakan dalam peneitian ini adalah :

1. Uji Validitas
a. Skala Citra Merek
b. Skala Minat Beli

2. Uji Reliabilitas

3. Uji Analisa Korelasi Bivariat

4. Uji Normalitas dengan Uji Kolmorgov-Smirnov.

\section{HASIL DAN PEMBAHASAN}

\subsection{Uji Validitas}

Uji Validitas menurut Arikunto (Mulyapradana, 2012) adalah suatu ukuran yang menunjukkan tingkat-tingkat kevalidan dan kesasihan dalam suatu instrumen. Pada penelitian ini menggunakan validitas ítem untuk mengetahui sejauh mana item-item yang ada mencakup keseluruhan faktor yang hendak diukur. Pengukuran ini menggunakan perhitungan Korelasi Product Moment dengan bantuan komputer, yaitu program SPSS Versi 12. 
Tabel 2. Hasil Uji Validitas Item Citra Merek

\begin{tabular}{|c|c|c|c|c|c|c|}
\hline & F1 & F2 & F3 & F4 & F5 & TS \\
\hline F1 Pearson Correlation & 1 & $823 * *$ &, $741^{* *}$ & $821 * *$ & $808^{* * *}$ & $900^{* * 2}$ \\
\hline Sig (2-tailec & &, 000 &, 000 &, 000 &, 000 &, 000 \\
\hline $\mathrm{N}$ & 30 & 30 & 30 & 30 & 30 & \\
\hline F2 Pearson Correlation & $0823 * *$ & 1 & $911^{* *}$ & $844 *$ & $802^{* *}$ & $944^{*}$ \\
\hline Sig $(2-$ &, 000 & &, 000 &, 000 &, 000 &, 00 \\
\hline $\mathrm{N}$ & 30 & 30 & 30 & 30 & 30 & 3 \\
\hline F3 $\quad$ Pearso &, $741^{* *}$ & $911^{* *}$ & 1 & $825 * *$ & $748^{* *}$ & $912^{* * *}$ \\
\hline Sig (2-taile &, 000 &, 000 & &, 000 &, 000 &, 00 \\
\hline $\mathrm{N}$ & 30 & 30 & 30 & 30 & 30 & 3 \\
\hline F4 $\quad$ Pearsor & $821^{* *}$ & $844^{* *}$ & $825^{* *}$ & 1 & $935^{* *}$ & $956^{*}$ \\
\hline Sig (2-tailed) &, 000 &, 000 &, 000 & &, 000 &, 00 \\
\hline $\mathrm{N}$ & 30 & 30 & 30 & 30 & 30 & 3 \\
\hline F5 Pearso: & $808^{* *}$ & $802 * *$ &, $748^{* *}$ & $935^{* *}$ & 1 & $927^{* *}$ \\
\hline Sig (2-tailed) &, 000 &, 000 & .000 &, 000 & & , \\
\hline $\mathrm{N}$ & 30 & 30 & 30 & 30 & 30 & 3 \\
\hline TS Pearson Correlation & $900^{* *}$ & $944^{* *}$ & $912^{* *}$ & $.956^{* *}$ & $927^{* *}$ & \\
\hline Sig (2-tailed) &, 000 &, 000 &, 000 &, 000 &, 000 & \\
\hline $\mathrm{N}$ & 30 & 30 & 30 & 30 & 30 & 3 \\
\hline
\end{tabular}

Sumber : Data Olahan SPSS v.12. 0, 2020

Dari tabel di atas (pojok kanan) dapat dilihat bahwa $\mathrm{r}$ hitung dari kepribadian merek sebesar $(0,900)$, konotasi merek $(0,944)$, keuntungan merek $(0,912)$, pemakai $(0,956)$ dan situasi $(0,927)$ itu lebih besar dari $r$ tabel $(0,3)$ itu berarti bahwa data ini valid dan artinya dapatdilanjutkan ke tahap berikutnya.

Tabel 3. Hasil Uji Validitas Item Minat Beli

\begin{tabular}{|c|c|c|c|c|c|}
\hline & F1 & F2 & F3 & $\mathrm{F} 4$ & TS \\
\hline F1 Pearson Correlation & 1 & $862 * *$ & $810^{* *}$ &, $738^{* *}$ &, $919 * *$ \\
\hline Sig (2-tailed) & &, 000 &, 000 &, 000 &, 00 \\
\hline $\mathrm{N}$ & 30 & 30 & 30 & 30 & 3 \\
\hline F2 Pearson Correlation & $862^{* *}$ & 1 & $894 * *$ & $.752^{* * *}$ & $951^{* *}$ \\
\hline Sig (2-tailed) &, 000 & &, 000 &, 000 &, 00 \\
\hline $\mathrm{N}$ & 30 & 30 & 30 & 30 & \\
\hline F3 Pearson Correlation & $810^{* *}$ &, $894^{* *}$ & 1 &, $721^{* *}$ & $932^{*}$ \\
\hline Sig (2-tailed) &, 000 &, 000 & &, 000 &, 00 \\
\hline $\mathrm{N}$ & 30 & 30 & 30 & 30 & 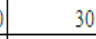 \\
\hline F4 Pearson Correlation &, $738 * *$ &, $752 * *$ &, $721^{* *}$ & 1 & $879 *$ \\
\hline Sig (2-tailed) &, 000 &, 000 &, 000 & &, 00 \\
\hline $\mathrm{N}$ & 30 & 30 & 30 & 30 & ) \\
\hline TS Pearson Correlation & $919 * *$ & $951^{* *}$ & $932 * *$ & $879 * *$ & \\
\hline Sig (2-tailed) &, 000 &, 000 &, 000 &, 000 & \\
\hline $\mathrm{N}$ & 30 & 30 & 30 & 30 & \\
\hline
\end{tabular}

Sumber : Data Olahan SPSS v.12. 0, 2020

Dari tabel di atas (pojok kanan) dapat dilihat bahwa $r$ hitung dari Fungsional sebesar (0,919), Emosional (0,951), Sosial $(0,932)$, dan Rasa ingin tahu $(0,879)$ itu lebih besar dari $r$ tabel $(0,3)$ itu berarti bahwa data ini valid dan artinya dapat dilanjutkan ke tahap berikutnya.

\subsection{Uji Reliabilitas}

Setelah mendaptkan item yang memenuhi kriteria validitas, maka dilakukan pengukuran reliabilitas instrumen penelitian dengan menggunakan Alpha Cronbach dalam program SPSS 12 for Windows. Menurut Arikunto (Mulyapradana, 2012) reliabilitas adalah suatu instrument cukup dapat dipercaya untuk digunakan sebagai alat pengumpul data karena instrument tersebut sudah baik.

Tabel 4. Uji Reliabilitas

\begin{tabular}{|ll|r|r|}
\multicolumn{3}{|c}{ Case Processing Summary } \\
\hline \multicolumn{1}{|c|}{} & \multicolumn{1}{|c|}{ N } & \multicolumn{1}{c|}{$\%$} \\
\hline Cases & Valid & 30 & 100.0 \\
& Excluded & 0 & .0 \\
& Total & 30 & 100.0 \\
\hline
\end{tabular}

a. Istwise deletion base on all Variabel

Tabel 5. Reliability Statistics

Citra Merek

\begin{tabular}{|c|c|}
\hline $\begin{array}{c}\text { Cronbach's } \\
\text { Alpha }\end{array}$ & $\mathrm{N}$ of Items \\
\hline 9677 & 5 \\
\hline
\end{tabular}

Sumber : Data Olahan SPSS v.12. 0, 2020

Dari tabel diatas bisa dilihat bahwa angka Cronbach's Alpha sebesar 0,9677 itu berartibahwa hasil dari perhitungan SPSS lebih besar dari 0,6. Oleh karena itu dapat disimpulkan bahwa instrumen penelitian yang digunakan untuk mengukur variabel Citra Merek dapat dikatakan reliabel atau handal.

Tabel 6. Reliability Statistics

Minat Beli

\begin{tabular}{|r|l|}
\hline $\begin{array}{c}\text { Cronbach's } \\
\text { Alpha }\end{array}$ & N of Items \\
\hline .8635 & \\
\hline
\end{tabular}

Sumber : Data Olahan SPSS v.12. 0, 2020

Dari tabel diatas bisa dilihat bahwa angka Cronbach's Alpha sebesar 0,8635 itu berarti bahwa hasil dari perhitungan SPSS 
lebih besar dari 0,6. Oleh karena itu dapat disimpulkan bahwa instrumen penelitian yang digunakan untuk mengukur variabel Minat Beli dapat dikatakan reliabel atau handal.

Pengujian reliabilitas untuk mengetahui sejauhmana alat ukur dapat memberikan hasil yang relative tidak berbeda apabila dilakukan pengukuran kembali terhadap gejala atau kondisi yang sama pada saat yang berbeda. Pengujian reliabititas instrumen dilakukan dengan menggunakan reliablitity analysis alpha croncbach. Secara teoritis besaran koefisien reliabilitas berkisar 0,00 sampai dengan 1,00. Dengan teknik ini berdasarkan kaidah reliabilitas menurut Guildford dan Frucher.

Tabel 7. Koefisien Reliabilitas

\begin{tabular}{|c|c|}
\hline Kriteria & Koefisien Reliabilitas \\
\hline Sangat Reliabel & $>0,9$ \\
\hline Reliabel & $0,7-0,9$ \\
\hline Cukup Reliabel & $0,4-0,7$ \\
\hline Kurng Reliabel & $0,2-0,4$ \\
\hline Tidak Reliabel & 0,2 \\
\hline
\end{tabular}

Sumber : (Mulyapradana, 2012)

\subsection{Uji Analisa Korelasi Bivariat}

Setelah item-item valid sudah diperoleh dari perhitungan anaisis item yang dilakukan. Analisis data penelitian ini diuji dengan menggunakan korelasi product moment pearson melalui program SPSS versi 12 for windows.

Berdasarkan hasil komputasi analisis bivariate antara citra merek dengan minat beli diperoleh $\mathrm{f}$ sebesar 0,332 dan $\mathrm{p}=0,000$ dengan $\mathrm{p}, 0,05$. Arah korelasi menunjukkan arah positif maka dapat dikatakan bahwa citra merek yang baik akan meningkatkan minat beli pada hand body lotion dan begitu pula sebaliknya citra merek yang buruk akan menurunkan minat beli pada hand body lotion.
Tabel 8. Hasil Uji Korelasi Bivariate

\begin{tabular}{|l|r|r|}
\hline & $\begin{array}{c}\text { Citra } \\
\text { Merek }\end{array}$ & $\begin{array}{c}\text { Minat } \\
\text { Beli }\end{array}$ \\
\hline Citra Merek & & \\
Person Correlation & 1 & .332 \\
Sig (2-tailed) &, & .000 \\
$\mathrm{~N}$ & 123 & 123 \\
\hline Minat Beli & & \\
Pearson Correlation & .332 & 1 \\
Sig. (2-tailed) & .000 &, \\
N & 123 & 123 \\
\hline \multicolumn{2}{|r|}{ Sumber : Data Olahan SPSS v.12.0,2020 }
\end{tabular}

Sumber : Data Olahan SPSS v.12. 0, 2020

Analisis data penelitian ini diuji dengan menggunakan korelasi product moment pearson atau Korelasi Bivariate melalui program SPSS versi 12 for windows. Berdasarkan hasil komputasi analisis bivariate antara citra merek dengan minat beli diperoleh $\mathrm{f}$ sebesar 0,332 dan $\mathrm{p}=$ 0,000 denganp,0,05. Arah korelasi menunjukkan arah positif maka dapat dikatakan bahwa citra merek yang baik akan meningkatkan minat beli pada hand body lotion dan begitupula sebaliknya, citra merek yang buruk akan menurunkan minat beli pada hand body lotion.

\subsection{Uji Normalitas dengan Uji Kolmorgov- Smirnov}

Tabel 9. Uji Normalitas Kolmorgov Smirnov

\begin{tabular}{|l|r|r|r|r|r|r|}
\hline \multirow{2}{*}{} & \multicolumn{3}{|c|}{ Kolmorgov-Sminor } & \multicolumn{3}{c|}{ Shapiro.Wilk } \\
\cline { 2 - 7 } & Statistic & df & Sig & Statistic & df & Sig \\
\hline Citra Merek & .059 & 123 & $.200^{*}$ & 984 & 123 & $.171^{8}$ \\
\hline Minat Beli & .091 & 123 & .013 & .982 & 123 & .092 \\
\hline
\end{tabular}

Sumber : Data Olahan SPSS v.12. 0, 2020

Berdasarkan tabel output SPSS di atas, dapat dilihat bahwa nilai signifikansi Asymp.Sig.(2-talled) sebesar 0,200 dan itu lebih besar dari 0,05. Maka sesuai dengan dasar pengambilan keputusan dalam uji normalitas kolmogorov-smirnov di atas, dapat disimpulkan bahwa data berdistribusi 
normal. Dengan demikian, asumsi atau persyaratan normalitas dalam model regresi sudah terpenuhi.

\section{KESIMPULAN DAN SARAN}

\subsection{Kesimpulan}

Berdasarkan hasil pengamatan dan pembahasan yang sudah di bahas peneliti mengenai Hubungan Antara Citra Merek Dengan Minat Beli Hand Body Lotion Pada Siswa-Siswi Kelas XI di SMA 2 Cipocok Jaya Kota Serang, makadapat disimpulkan sebagai berikut :

1. Berdasarkan hasil penelitian yang dilakukan membuktikan adanya hubungan secara bersama-sama yaitu variabel Citra Merek $\left(\mathrm{X}_{1}\right)$, dan Minat Beli $\left(\mathrm{X}_{2}\right)$, pada Hal ini ditunjukkan dengan nilai signifikansi sebesar 0,01 $(\mathrm{p}<0,05)$. Hasil analisis ini juga menunjukkan bahwa besarnya kontribusi variabel Citra Merek $\left(\mathrm{X}_{1}\right)$, dan Minat Beli $\left(\mathrm{X}_{2}\right)$ yang ditunjukkan dari nilai $\mathrm{R}$ Square yaitu sebesar 0,8635. Hal ini berarti bahwa kemampuan variabel-variabel Citra Merek $\left(\mathrm{X}_{1}\right)$ secara bersama-sama memberikan kontribusi Minat Beli $\left(\mathrm{X}_{2}\right.$ )adalah sebesar $86,4 \%$ sedangkan sisanya 13,6 \% dipengaruhi oleh variabel lain yang tidak diteliti oleh penulis.

2. Secara keseluruhan bahwa ada hubungan yang signifikan antara citra merek dengan minat beli hand body lotion pada siswa-siswi kelas XI di SMAN 2 Cipocok Jaya Kota Serang hal ini berdasarkan Berdasarkan hasil komputasi analisis bivariate antara citra merek dengan minat beli diperoleh $\mathrm{f}$ sebesar 0,332 dengan nilai signifikansi sebesar $0,01(\mathrm{p}<0,05)$.

\subsection{Saran}

Dari kesimpulan yang diuraikan diatasmaka saran dari penelitian ini sebagai berikut:
1. Bagi peneliti yang ingin mengembangkan dan melanjutkan penelitian disarankan melibatkan variabel-variabel yang bersifat internal (konsep diri dan kecerdasan emosional) maupun eksterna (gaya hidup dan kebiasaan) dengan melibatkan variabel-variabel lain diharapkan dapat terungkap secara detail variabel-variabel apa saja yang berhubungan dengan minat beli.

2. Berdasarkan hasil kategorisasi diketahui bahwa citra merek sisw-siswi SMAN 2 Cipocok Jaya Kota Serang terhadap minat beli tergolong baik. Kondisi demikian perlu dipertahankan agar siswa-siswi dapat selalu membedakan suatu merek dengan merek lainnya akan menjadikannya dasar perilaku membeli. Sebaiknya siswa tidak terlalu menanggapi iklan produk secara berlebihan sehingga akan mendorong siswa untuk memiliki pola hidup konsumtif.

\section{DAFTAR PUSTAKA}

A. Shimp, T. (2014). Komunikasi Pemasaran Terpadu dalam periklanan dan Promosi. Komunikasi Pemasaran Terpadu Dalam Periklanan Dan Promosi.

https://doi.org/10.1017/CBO97811074 15324.004

Anekasari, R. (2017). Psikologi Perkembangan (Mo. Nasrudin (ed.); 1st ed.). Penerbit NEM.

Berkman, H.W. Gilson, C. (1981). Consumer Behavior; Concept and Strategies. Kent Publishing Company.

Elshifa, A. (2018). Pengaruh Leader Member Exchange (LMX) dan Komitmen Organisasi terhadap Kinerja Karyawan dengan Mediasi Organizational Citizenship Behavior (OCB) (Studi Kasus pada Karyawan Kospin Jasa Pekalongan). Ecomomicus, 9(1), 25-39. 
Endro, A., \& Achmad, F. (2015). Pengaruh Persepsi Kualitas Produk, Citra Merek Dan Promosi Terhadap Minat Beli Konsumen Ban Achilles Di Jakarta Selatan. Jurnal Mix.

Foxall, G. R., Goldsmith, R. E., \& Brown, S. (1998). Consumer Psychology for Marketing (2nd ed.).

KBBI. (2016). Kamus Besar Bahasa Indonesia ( KBBI ). In Kementerian Pendidikan dan Budaya.

Kotler dan Amstrong. (2008). PrinsipPrinsip Pemasaran Jilid I. In Erlangga.

Kotler, P., \& Keller, K. L. (2009). Manajemen pemasaran Jilid 1. In Jakarta.

Lusi, S., Leonardo, B. H., \& Andi, T. H. (2016). Pengaruh Citra Merek, Sikap Merek, Kesadaran Merek Dan Kualitas Merek Terhadap Ekuitas Merek, Hand \& Body Lotion Vaseline ( Studi Kasus Di Kecamatan Pringapus, Kabupaten Semarang ). Journal of Management.

Mulyapradana, A. (2012). Universitas Indonesia Terhadap Intensi Turnover Karyawan.

Mulyapradana, A., Rosewati, T., \& Muafiq, F. (2020). Pengaruh Pemberian Kompensasi terhadap Kinerja Karyawan Hotel Dafam Kota Pekalongan. Widya Cipta: Jurnal Sekretari Dan Manajemen. https://doi.org/10.31294/widyacipta.v4 i1.6585

Parmin, P. (2013). Analisis Pengaruh Daya Tarik Iklan, Kualitas Produk, Dan Citra Merek Terhadap Minat Beli Konsumen Teh Celup Sariwangi di Kecamatan Adimulyo. Fokus Bisnis: Media Pengkajian Manajemen Dan Akuntansi, 12(1), 59-73. https://doi.org/10.32639/fokusbisnis.v1 $2 \mathrm{i} 1.60$

Roisah, R., \& Riana, D. (2016). Telaah Hubungan Citra Merek, Kualitas Produk Dan Keputusan Pembelian Konsumen. Jurnal Ecodemica: Jurnal Ekonomi, Manajemen, Dan Bisnis.
https://doi.org/10.31311/JECO.V4I1.3 51

Sari, N., \& Widowati, R. (2014). Hubungan Antara Kesadaran Merek, Kualitas Persepsian, Kepercayaan Merek Dan Minat Beli Produk Hijau. Jurnal Manajemen Bisnis.

Savitri, I. A. P. D., \& Wardana, I. M. (2018). Pengaruh Citra Merek, Kualitas Produk dan Persepsi Harga Terhadap Kepuasan dan Niat Beli Ulang. E-Jurnal Manajemen Universitas Udayana. https://doi.org/10.24843/ejmunud.2018 .v07.i10.p19

Schiffman, L., \& Kanuk, L. L. (2008). Perilaku konsumen. Jakarta: Indeks.

Sugiyono. (2016). Metodologi Penelitian Kuantitatif, Kualitatif, dan R\&D. In CV

Alfabeta. https://doi.org/https://doi.org/10.3929/ ethz-b-000238666 